\title{
Planetary Exploration in Extremis
}

By Peter J. Westwick

Excerpted from Into the Black: JPL and the American Space Program, 1976-2004, by Peter J. Westwick, Yale University Press, 2006. Reproduced by permission.

Bruce C. Murray, professor of planetary science and geology, emeritus, was director of the Jet Propulsion Lab from 1976 to 1982, succeeding William

Pickering, who had served since 1954.
Even as the Voyager spacecraft completed their triumphant encounters with Saturn, Professor of Planetary Science Bruce Murray, then the director of the Jet Propulsion Laboratory, was waging a fierce campaign to save Voyager, the rest of the lab's flight projects, and perhaps the lab itself from extinction. The crisis in planetary exploration reached its peak in 1981, but it was germinating when Murray arrived in 1976 and first blossomed the following summer, impelling lab managers and Caltech trustees into the political arena. Paradoxically, the public enthusiasm for solar system exploration was not translating into Congressional support: as NASA's deputy administrator, Hans Mark, said at a National Academy of Sciences colloquium, "[The] problem is that Americans don't vote on [the] basis of the space science program achievements."

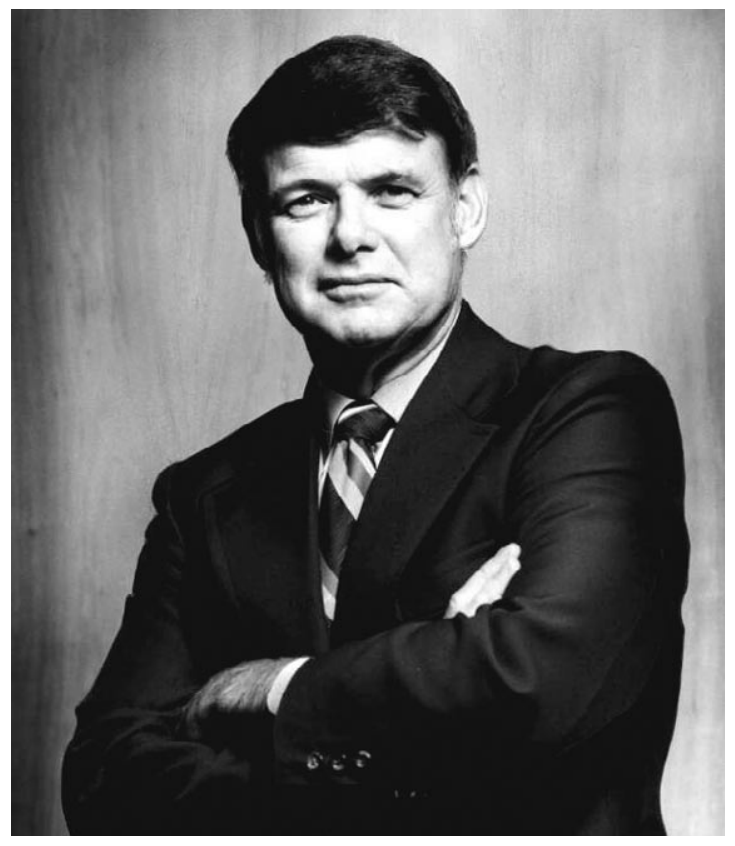

http://www.jpl.nasa.gov
There were several reasons for this: the slackening of the space race after the Apollo missions to the moon and the emergence of more pressing national priorities; continued contention between the human and robotic space programs, exacerbated by the space shuttle; increasing competition within NASA's space-science program from space-based astronomy [the Hubble Space Telescope had, by the early 1970s, reached the formal design stage] and earth sciences [the first Landsat launch occurred in 1972]; and allocation of priorities within the planetary program, which at times would array parts of JPL against each other.

In 1976, NASA commissioned a study of public interest. The study concluded, "The picture of NASA that is in focus is Big Budget, Big Spectaculars and, bottom line, a hundred pounds of moon rocks." NASA was not doing much to dispel the big-budget image. In 1972 President Nixon had approved the space shuttle program. To win approval, NASA had cut its cost estimates to $\$ 5$ billion and inflated the projected number of launches to sixty per year. Both proved unrealistic. By the time the first shuttle flew in 1982, four years after the expected initial launch date, the program had doubled in cost and could deliver only about six flights in its first two years of operation. In the meantime, to ensure customers for the shuttle $N A S A$ had stopped buying expendible rockets, leaving planetary missions with no ride into space.

\section{Purple Pigeons and Gray Mice: Or, How to Fill a Bathtub}

The decline of the planetary program manifested itself at JPL first in the projected rampdown from Viking and Voyager. The Viking workforce dropped off sharply from more than 400 staff in 1975 to almost zero by 1977; Voyager would undergo a similar decline starting in 1977. The lab expected to ramp back up for the Jupiter orbiterprobe and a possible lunar orbiter starting in 1978, but that left a deep two-year dip in the graph of 
Right: Voyagers I and 2

were launched in 1977.

Far right: The boulderstrewn vastness of Mars's

Utopia Planitia reaches to

the horizon nearly two

miles from Viking 2, which,

with its twin Viking I,

made the first successful

landings on the red planet

in 1976 after three unsuc-

cessful Soviet attempts.
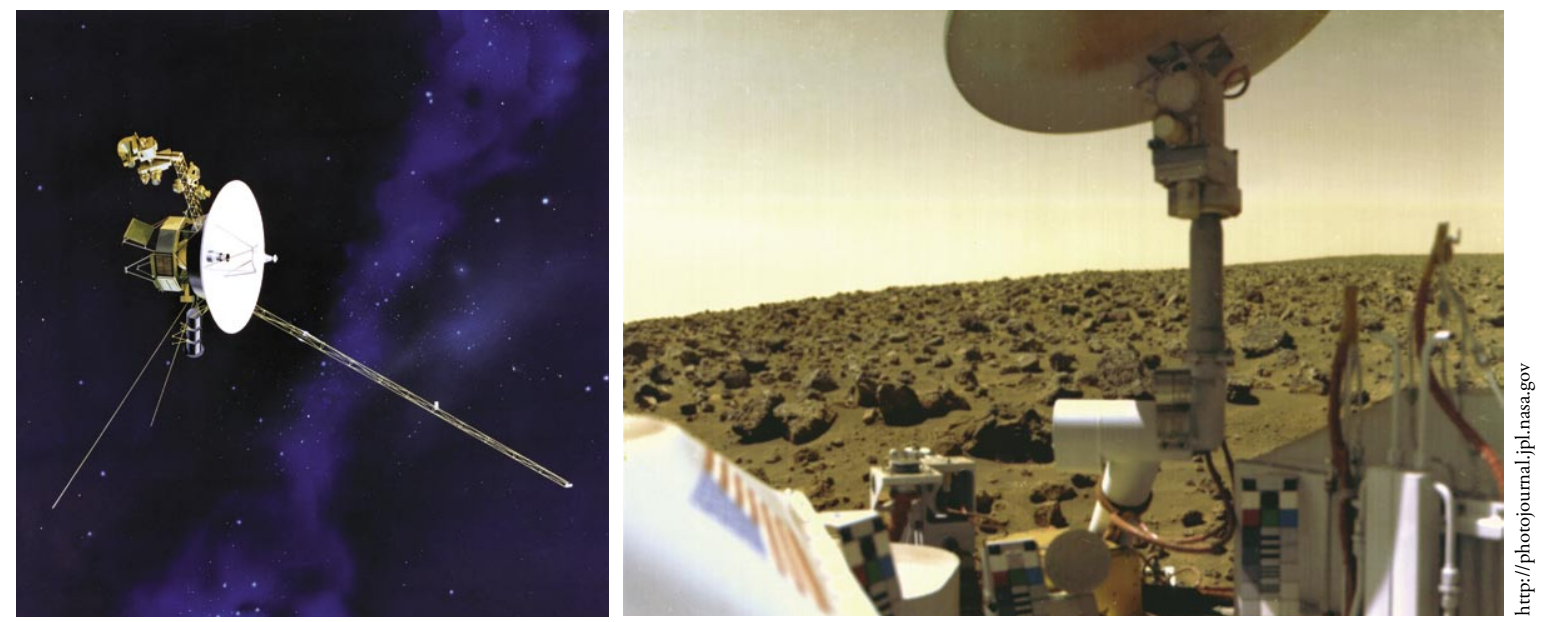

staff levels. Even if the Jupiter or moon missions were approved for 1978, the lab would have to lay off staff; if neither project were approved that year, perhaps $500 \mathrm{JPL}$ employees and a similar number of contractor staff at JPL would lose their jobs.

The lack of new missions for 1977 and 1978 became known as the "bathtub," after the U-shaped bend in the workforce charts. The staffing shortfall had long-term implications. Experienced engineers were not easily replaced; despite the documentation of systems engineering, lab staff viewed their expertise as a form of tacit knowledge. Murray wrote to NASA's space science manager that "no amount of documentation or procedural manuals can enable

Murray dubbed the collective of missions the "purple pigeons." The name addressed perceptions of a lack of pizzazz at NASA, with the colorful pigeons replacing the "gray mice" generated by the current planning process.

inexperienced engineers to by-pass entirely the many subtle opportunities for potentially serious, even catastrophic mistakes. The knowledge and understanding now embodied in our staff was painfully acquired in the 1960s and has been maintained by the subsequent continuity of project activities." The argument that JPL's expertise was a national resource meriting upkeep by the federal government would become a recurring theme.

JPL managers would seek to fill the bathtub in part with non-NASA work, especially in energy and then defense, but they also sought to keep planetary missions flowing. One of Murray's first acts as director in April 1976 was to assemble a team to come up with imaginative new missions. The group spent three months brainstorming and arrived at a list of seven candidates: Mars rovers; a Venus radar orbiter; a tour of Jupiter's inner moons with a landing on Ganymede; an orbiter to Saturn with a lander on Titan; a flyby of several asteroids; an unmanned station on the moon's south pole; and development of a "solar sail," which would use solar radiation pressure to propel a mission to Halley's comet.

Murray dubbed the collective of missions the "purple pigeons." The name addressed perceptions of a lack of pizzazz at NASA, with the colorful pigeons replacing the "gray mice" generated by the current planning process. Murray intended the pigeons to combine "first-rate science ... . with broad popular appeal"; the popular aspect, he noted, was required to generate and sustain political support for the several years from project approval to launch. The purple pigeons coincided with the Viking encounter and aimed to capitalize on the media presence; when journalists asked what was next for the planetary program, Murray and the JPL public affairs people pushed the pigeons. The colorful pigeons caught the media's eye, and NASA soon approved supplemental funds for the solar sail and Mars missions and added other pigeons to its long-range plans. By the end of 1976 Murray concluded that "the outlook is more encouraging now than for some time."

The lab meanwhile was awaiting formal approval of the Jupiter Orbiter-Probe (JOP) as a 1978 new start. With support from scientists, NASA, and OMB, approval seemed likely. But on 4 May 1977, the House appropriations subcommittee responsible for NASA's budget deleted all funds for the project. The chair of the committee, Rep. Edward Boland, had consistently pressed NASA to prioritize, and he now correctly judged the space telescope a higher priority for NASA and the Space Science Board. After the Senate appropriations subcommittee approved the Jupiter mission, and a House-Senate conference committee failed to resolve the impasse, the matter returned to the House for a special vote.

In the week before the vote, Murray mobilized the lab to defeat Boland. The campaign recruited 
the California congressional delegation, the House and Senate science committees, planetary scientists, sympathetic media outlets, and the sci-fi community, including thousands of Star Trek fans convening for their annual convention. On July 19 the House engaged in a dramatic floor debate over the Jupiter proposal. Boland and members of his committee stressed that they did not oppose NASA's mission or even the value of this specific project, bur rather felt compelled to impose some discipline on NASA and space scientists. A succession of congressmen rose to defend the project and the overall deep-space program. Aside from scattered references to technological spin-offs and international prestige and cooperation, their justifications appealed mainly to the goal of space exploration, the importance of the science results and their relevance to terrestrial climate research, and the need to sustain the expertise at JPL. The time allotted for debate expired, and Boland called for a quorum. The final tally produced a sweeping victory for JPL: 280 supporting the Jupiter Orbiter-Probe to 131 opposed, with 22 abstentions.

The possible loss of JPL's next major flight project was "a rude awakening" to lab staff. The

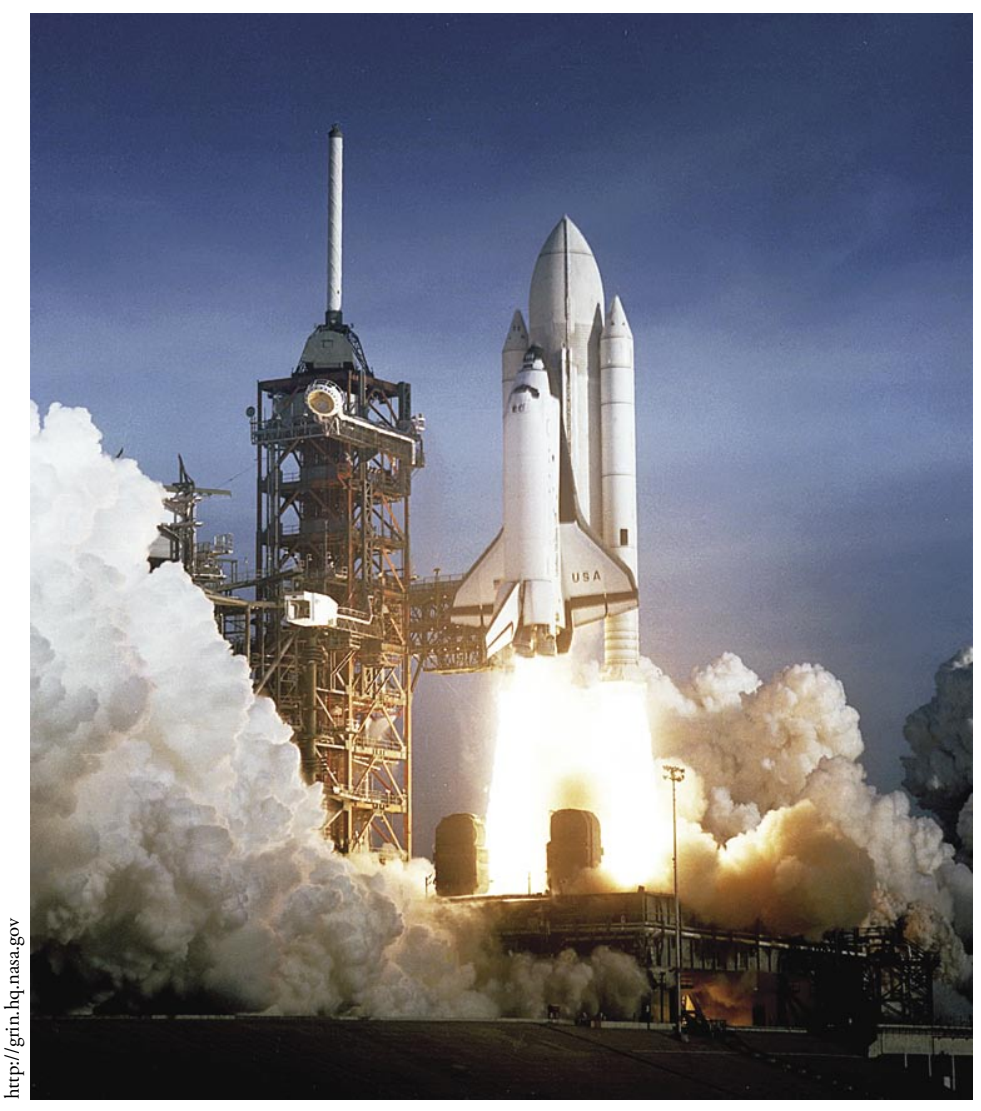

The first Space Shuttle mission, STS-I, was launched on April 12, 198 I.

Columbia, piloted by Robert Crippen and commanded by John Young, spent 54 hours in orbit and traveled more than a million miles before the test flight ended at Edwards Air Force Base in California. planetary program did appear to settle down after the flurry of activity to save the Jupiter mission, which was soon renamed Galileo. But while Galileo sparked the recovery, its early development foreshadowed future trials. With no expendible rockets in NASA's inventory, Galileo was at the mercy of the shuttle schedule. JPL wanted to launch in January 1982 to take advantage of a gravity-assist trajectory past Mars to Jupiter. By 1979, however, it was apparent that the available shuttle at that time would be overweight and underpowered, and hence unable to lift the 30-ton Galileo spacecraft (a 2.5-ton spacecraft plus booster and support equipment). To meet the launch date, NASA asked JPL to split the spacecraft in two and launch the orbiter and probe separately. But that plan required the purchase of an additional transfer stage at $\$ 100$ million, almost one-fourth the total project cost at that point. More important, a split launch required two shuttles-and NASA would not have two by 1982 . So Galileo was postponed until 1984, when a second shuttle would be available, with the delay inflating the cost increase to \$225 million. The saga of Galileo would not end there.

The delays and overruns in the shuttle program heralded an impending crisis. As the new decade dawned, Science magazine was reporting that planetary science was "on the brink again." The newfound pessimism stemmed from a lack of new starts. Lab managers had planned for a lunar orbiter, Venus radar orbiter, Halley's comet rendezvous, and Mars sample return, but none of these won approval through 1981. In 1978 NASA and JPL did win approval for the International Solar Polar Mission (ISPM), which would send two spacecraft, one American and one European, over opposite poles of the sun to map solar radiation out of the ecliptic plane for the first time. But the ISPM spacecraft would be built by industrial contractors and would thus engage only a few dozen staff at JPL, and in 1980 it had its budget halved, forcing a two-year delay in the launch.

Some of the crisis was self-inflicted. JPL mission planners presented congressional critics with fat targets, evident especially in Mars mission planning. Viking had revealed a Martian environment chemically hostile to life, suggesting that any life on Mars would have to be concentrated in remote oases or buried underground; hence scientists sought either rovers or penetrators. JPL quickly drew up plans in early 1977 for two missions to Mars in the 1980s, an orbiter/rover to launch in 1984, and a sample return to launch in 1988. The first soon evolved into a proposal for a 400-kilogram rover capable of ranging 100 kilometers; the cost reached $\$ 1.4$ billion - and NASA cost reviewers thought JPL had low-balled the figures to win approval.

Even after the threat to Galileo in 1977, Mars planners had continued to disdain a lower-cost 
polar orbiter, on the theory that several smaller projects would be harder to sell than one big one. Although a few planetary scientists argued for an incrementalist approach, the majority soon abandoned plans for the billion-dollar rover in favor of a sample return that would cost twice as much; by contrast, the Jupiter proposal targeted by Boland was for $\$ 410$ million. The rallying cry of "sample return or nothing," although based on a political calculation, again suggests a lack of political acumen among JPL managers and planetary scientists, who failed to recognize the prevailing political winds and instead indulged what one NASA manager called "delusions of grandeur."

A tendency toward cost growth of JPL projects did not encourage political support. Galileo quickly ran into cost overruns, which also afflicted the Venus Orbital Imaging Radar (VOIR). Initial studies of a Venus radar orbiter began at JPL in 1971 and received a boost from the purple pigeons. By 1979 the lab had developed a formal proposal for VOIR, to launch in 1984. Its main instrument was a synthetic aperture radar, to penetrate the clouds of Venus and compare its hothouse environment to the frigid desert of Mars and Earth's more hospitable climate. NASA managers, however, expressed concern "about the high cost of this mission" — \$400 million—and asked JPL to find ways to reduce it. By 1981 cost estimates had far surpassed the levels that had alarmed NASA and now approached $\$ 700$ million.

The persistent effort to win a mission to Halley's comet would become the most visible victim of the planetary decline.

VOIR also encountered competition from other JPL proposals. Although NASA's "roles and missions" review had removed Ames and Langley from the planetary program, that just displaced competition to within JPL, where champions of particular projects squared off. VOIR planners in particular jockeyed against a Halley mission. Halley's orbital period of 76 years was due to return the comet to the inner solar system in the mid-1980s, and JPL in the mid-1970s began planning to take advantage of this once-in-a-lifetime chance. Halley met Murray's mandate that missions combine popular and scientific interest: its periodic and very visible appearance had attracted public attention throughout recorded history; and in the early 1970s space scientists had identified comets as a prime desideratum for inspection because they could provide clues to the initial constitution of the solar system. Halley's retrograde and highly eccentric orbit and high velocity, however, put it out of reach of conventional chemical propulsion. NASA and JPL managers then shot down a purple pigeon, the proposal to fly a solar sail to Halley, and an alternative proposal using

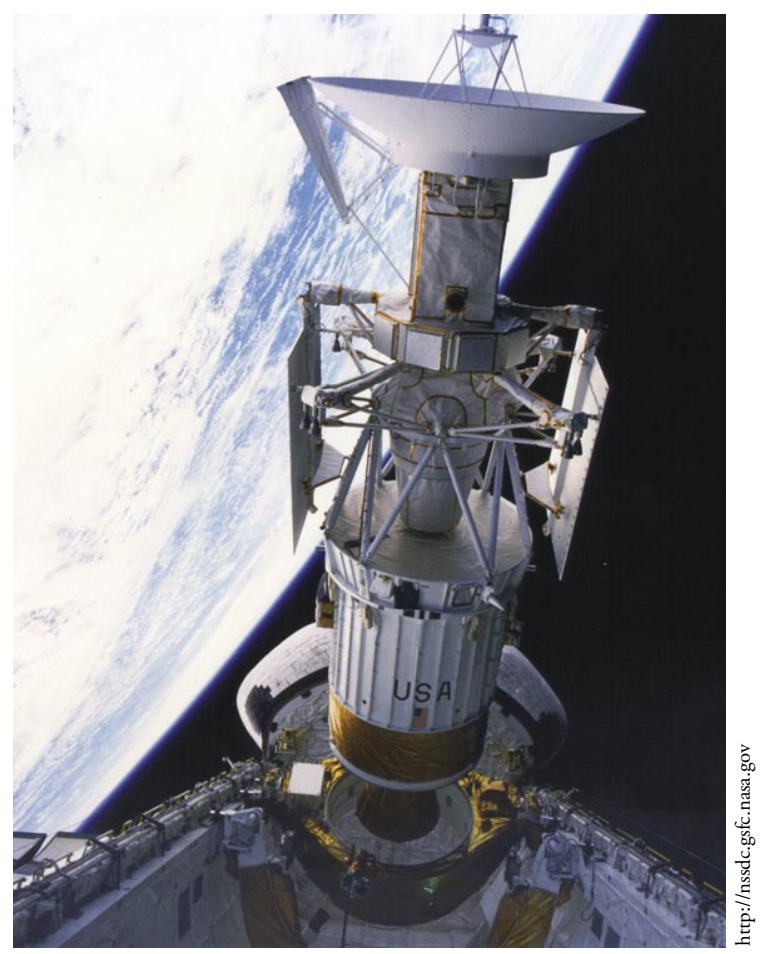

The Magellan spacecraft-seen here as it was released from the space shuttle Atlantis's payload bay in 1989-was a downscaled version of VOIR.

solar-electric propulsion, also known as ion drive, saw its cost estimates balloon to $\$ 200$ to $\$ 300$ million. By 1979 JPL still had no Halley mission.

The persistent effort to win a mission to Halley's comet would become the most visible victim of the planetary decline. Murray meanwhile tried to regenerate the excitement of the purple pigeons, by convening another study group in 1979 to study "far-out" ideas for deep-space missions twenty to forty years in the future. Replicating the purple pigeons might have seemed a dubious exercise in retrospect: four years after the pigeons first flew, none of them had come to roost in approved flight projects. Beset by annual battles to save existing missions, NASA managers had little inclination to ponder the possibilities for forty years in the future. Any interest they might have had was definitely dispelled by a redoubled assault on the deep-space program.

\section{Black September}

The crisis in planetary exploration came to a head in 1981. If Murray spoke of low morale and soul-searching at JPL in October 1980, the effects of the presidential election the next month would not help. Ronald Reagan had campaigned on a platform of fiscal austerity, except for national 
The Centaur upper-stage rocket was developed in the

1960s at the Propulsion Systems Laboratory at Lewis

Research Center, now John H. Glenn Research Center. An

ambitious design using liquid oxygen and liquid hydro-

gen-the first to use hydrogen as a fuel-it underwent a

difficult development period before becoming a workhorse

that launched hundreds of NASA, commercial, and military

payloads.

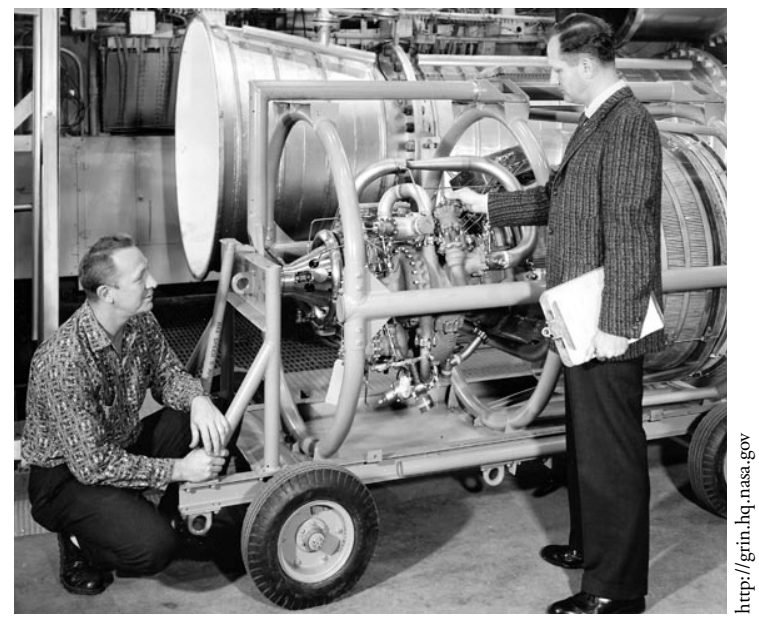

Halley's comet as shot

from Easter Island on

March 8, 1986, by W.

Liller for the International

Halley Watch Large-Scale

Phenomena Network. security, and upon inauguration he immediately set about implementing it. In February 1981 Reagan's OMB not only cancelled VOIR, but it also required NASA to cancel either the space telescope, Galileo, or the solar-polar mission, even though each was years into development. NASA elected to kill the solar-polar mission, an unprecedented cancellation of a well-established project that also involved international cooperation.

The budget actions led Murray to paint a bleak picture to Congress: "Frankly, ... . the U.S. deep space program is in deep jeopardy and even may face extinction." Although spared the budget ax, Galileo now faced additional delays, again owing to the launch vehicle. The problem now concerned the so-called Inertial Upper Stage (IUS), a new solid-fuel rocket that would boost the spacecraft from the shuttle's orbit. In 1979, even as NASA decided on the split-launch configuration, problems with IUS performance required JPL to design new gravity-assist trajectories to reach Jupiter, and also spurred Representative Boland to press NASA to use the well-tested, liquid-fuel Centaur instead of the problematic IUS. The more-powerful

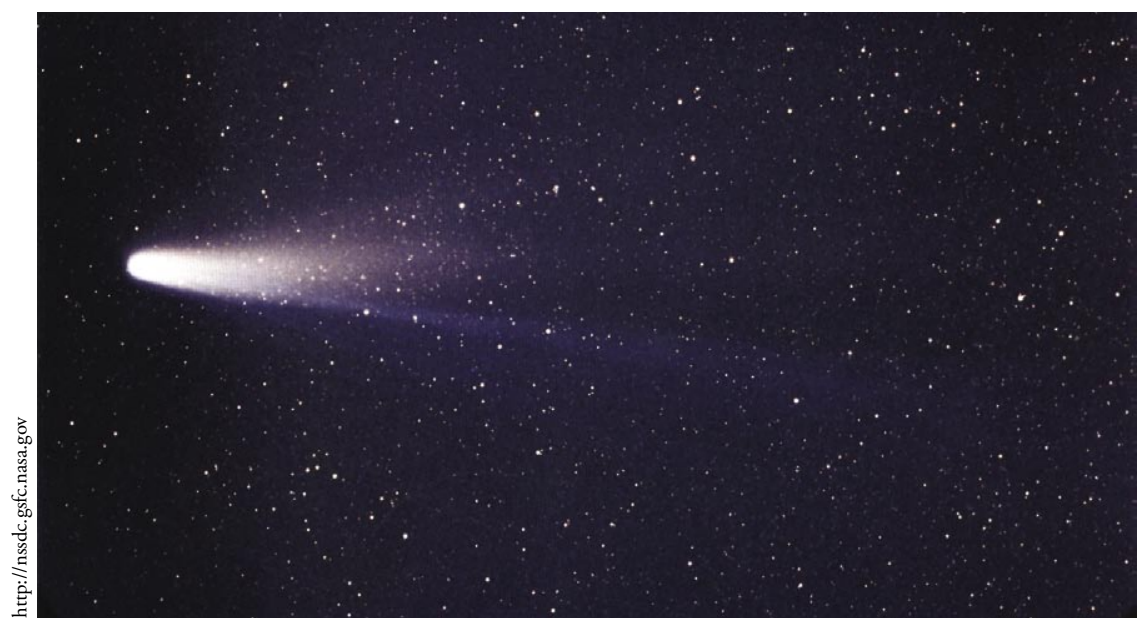

Centaur allowed a return to the original singlelaunch configuration of the Galileo orbiter and probe together, at the cost of a one-year delay in the launch, to 1985. JPL thus embraced the plan, and NASA committed to the Centaur in January 1981. The decision, however, made Galileo dependent on a redesign of the Centaur, with its own technical and political hurdles; and the additional delay-eventually to 1986-would have important consequences. And Galileo engineers returned yet again to the drawing board to reintegrate the spacecraft and plot a new trajectory.

The Halley mission meanwhile was undergoing its own parallel odyssey. After the demise of the Halley plans of 1979, JPL the next year proposed a low-cost Halley Intercept Mission (HIM), with "low cost" soon defined as about $\$ 300$ million. But comet scientists had earlier stated their distaste for a simple flyby, and NASA noted as well that the European Giotto mission to Halley would accomplish many of the same objectives. Like the Grand Tour in 1971, the Halley intercept suffered from a lack of advocacy within NASA, the agency that is supposed to back space projects, despite indications of support from OMB, usually the enforcer of austerity. A Halley mission became Murray's personal hobbyhorse, and he made a determined push to procure it. Why did he perceive a Halley mission as so crucial? Since the 1960s JPL was accustomed to having two major flight projects in development, with one expanding while the predecessor ramped down. But after Viking and Voyager the lab had only one team, Galileo, at full strength. VOIR could provide only a partial stopgap, since it would be built by industrial contractors; a Halley spacecraft promised to employ perhaps three times as many staff as VOIR. Along with institutional considerations, Murray personally viewed Halley as a unique chance to combine bold exploration with solid science and to make the first visit to an object of historical fascination. But Murray's fixation with Halley would have its costs, both within JPL and without. 
To replace HIM, JPL naturally suggested HER: Halley Earth Return, which would fly by Halley, unroll a long thin plastic tube "like a Chinese New Year party whistle" to sweep up cometary particles, then reel the tube back in and swing the spacecraft back toward Earth to return the sample. The plan quickly earned approval from the Space Science Board, and it offered a different approach than the European or Soviet Halley missions. But after a month of negotiations between NASA and the White House, on 30 September 1981 NASA directed Murray to stop all work on Halley missions.

The official end of JPL's hopes for Halley came as a jolt to Murray, who spoke bitterly of "Black September." That was not all. First, budget cuts on the Centaur project again put Galileo at risk, until JPL designers came up with yet another gravity-assist trajectory to get to Jupiter on the IUS booster. Then NASA floated a proposal to shut off the Voyager spacecraft, saving \$222 million by foregoing the Uranus and Neptune encounters. It finally became clear that not just single projects but the entire deep-space program was at stake. In summer 1981 the OMB cut $\$ 1.1$ billion from NASA's budget request. The new NASA administrator, James Beggs, insisted that such a shortfall would require dropping one of NASA's major programs, such as the shuttle, earth applications, or planetary exploration, and requested higherlevel policy approval. But he did offer a suggestion. At his confirmation hearings in June, Beggs had called planetary exploration "a hallmark of the agency. It would be a disaster if we gave it up." He now pushed the planetary program on the table as a high-stakes wager in the budgetary standoff, naming it as the first item NASA would be willing to cut. He again cited the program's value, but he ranked it below astronomy in immediate potential: "the most important missions" in deep space had already been done, and the next phase of landers and sample returns could await the shuttle. $\mathrm{He}$ added, "Of course, elimination of the planetary exploration program will make the Jet Propulsion Laboratory in California surplus to our needs."

The budget standoff continued through the fall, as dire rumors swirled concerning JPL's possible demise. The lab got little support from Reagan's science advisor, George Keyworth. In an interview published 2 December, a week before the final budget review, Keyworth "recommended halting all new planetary space missions for at least the next decade," in favor of astronomy and shuttle-borne experiments. He soon backtracked, stating that he did not propose ending missions altogether, just doing them more cheaply. Despite the public statements, Keyworth's testimony to the budget review board supported the decision to cancel Galileo and VOIR; "the cut in planetary exploration represents an example of good management."

JPL likewise lacked support from key elements of NASA. In particular, Hans Mark, deputy to
Beggs, proved an unreliable ally. Mark had long viewed the space shuttle as the focus of the space program, a necessary step toward the longer goal of a space station, and also held an ambivalent view of planetary exploration. In 1975 he had noted the substantial investment in the program, from which he believed "no fundamental or unexpected discovery" had emerged. And the program itself, he observed two years later, was running out of steam: "we have reached a point in the planetary exploration where, for the missions planned between now and the early 1980's, we will have done just about everything we can given our current technology. In other words, we soon will have 'saturated' our capabilities."

Mark brought these views with him to NASA. In August 1981 Mark and his aide Milton Silveira circulated a long-range plan for NASA. The document noted the space agency's role in scientific exploration, but it urged a focus on shuttle-borne experiments, especially for astronomy or cosmology, and a hiatus in planetary exploration until the construction of a space station as a base for spacecraft launch and sample return. As for what to do with JPL, Mark had long-held opinions on that too, which reinforced his views on the expendability of planetary exploration; JPL would have to seek other sponsors, which to Mark meant the military. He was thus pursuing, in parallel, a campaign to enlist JPL's skills for the Department of Defense.

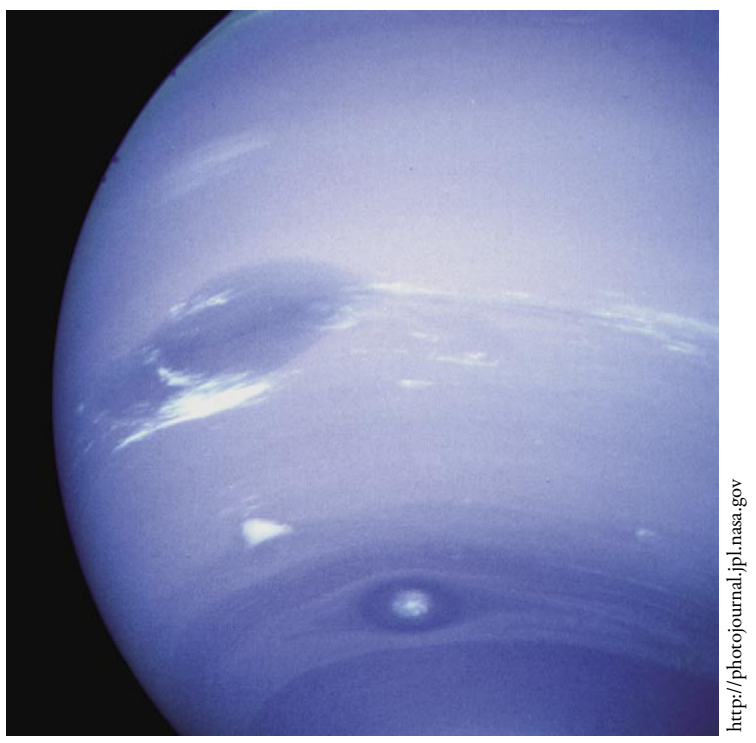

Had NASA been forced to turn off the Voyagers in 1981, our best view of Neptune would remain a fuzzy point of light in a telescope. This photo combines two images taken by Voyager 2's narrow-angle camera, and includes the Great Dark Spot (middle), a bright feature below it nicknamed "Scooter," and the bright-cored "Dark Spot 2" further below. 
Planetary Society cofounders Bruce Murray (seated, at left), Cornell astronomy professor and science popularizer Carl Sagan (seated, at right), and Louis Friedman (standing behind them), when the organization was incorporated in

1979. Behind Sagan is Harry Ashmore, a Pulitzer Prizewinning journalist and leader in the Civil Rights movement, who served as an invaluable advisor.

\section{Into the Political Arena}

Mark's statements on the planetary program undermined NASA's defense of JPL. Beggs did not help with his negotiating ploy of August, which backfired in December when the OMB cited his assignment of a lower priority to the deep-space program in its arguments before the budget review board. With a lack of advocacy at key levels, JPL undertook its own political campaign, one that would bring lobbying for programmatic goals to a new level of coordination and organization. But Murray first had to overcome an initial aversion to political activism, instilled not so much by principle as by practical considerations of JPL's relations with NASA. In 1976, for example, several JPL staff proposed Project Columbus, a long-term planetary program of one launch per year through 1992; the planners, however, bypassed NASA and took the proposal straight to OMB and Congress. Murray quickly reined them in and considered firing their leader, Lou Friedman, for insubordination.

A few years later Murray would institutionalize political freelancing far beyond that undertaken by Friedman, as Murray himself would admit. The congressional struggle over the cancellation of the Jupiter mission in summer 1977 provided the first test for Murray's misgivings. There remained perceptions of limits. NASA, at least, thought the lab had crossed a line. A legal affairs manager chastised Murray in May about direct contacts between JPL and Congress and reminded him that NASA policy required all congressional contacts with NASA personnel to go through his office. The lab's lawyers, however, pointed out that JPL was not a NASA field center; JPL staff were Caltech employ- ees and as such were not bound by NASA's policy. JPL's distinctive, dual status as a Caltech-run lab under NASA thus gave Murray and his managers leeway for lobbying. They also took refuge in semantics. What, exactly, constituted lobbying? The lab's NASA liaison was careful to refer instead to the "education" of Congress.

Murray and his staff also attended to the sources and justifications for political support. JPL had started as an army lab, which gave it a strong political advocate, but its new mission in planetary spacecraft made its main political constituency the community of planetary scientists - a narrow group with little political clout, as interest groups go. In the late 1970 s Science magazine estimated that the community numbered about " 600 or so" scientists in the United States. And it was competing with a formidable array of other interests, within NASA and without, for a share of the federal budget. Since JPL did most of its work in-house, the lab's projects elicited little political support from industry. To broaden the constituency, Murray and his friend Carl Sagan in late 1979 created the Planetary Society, together with Friedman. The society quickly built up a membership of 70,000 in its first year, a substantial base of enthusiasts to enlist in support of JPL's political initiatives.

Why should the public get excited about very expensive missions that return data on distant planets to a small group of planetary scientists? Murray appealed to the ideal of exploration: "More than just science is involved, and it should be-for what 
"Bruce, you have a good fight and an important one, and it's time to use these

big guns." - Mary Scranton

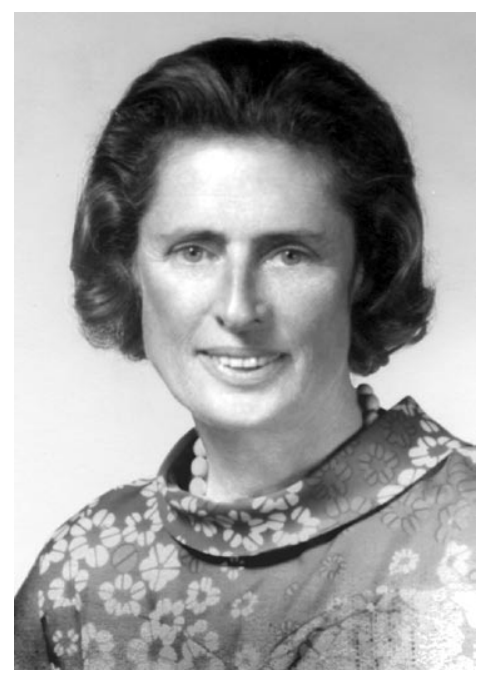

Caltech Trustee Mary Scranton it has cost. If there isn't a justification beyond what you might call narrow scientific objectives, then planetary is far overpriced in terms of what it has cost to accomplish. The reason it has been justified and continues to be is because it has broad cultural and social significance beyond the changing of the perceptions of individual scientists." Similar attitudes permeated NASA. Program manager Dan Herman observed that "above a certain dollar level, science-for-science sake is not a salable commodity in the planetary program area"; missions had to include exploration.

The decline of planetary prospects in 1980 quickened political activity at the lab, inspired by the rescue of Galileo in 1977. In its political campaign to defend the deep-space program, JPL had an important ally in the Caltech board of trustees. As part of Caltech, an elite institution with friends in high places, Murray and the lab sought to capitalize on connections to the inner circles of government. In 1976 Murray had created an advisory council for JPL, consisting of Caltech faculty, trustees, and eminent public citizens, to provide a source of high-level advice but also advocacy. An especially dedicated partisan was trustee Mary Scranton, wife of William Scranton, a one-time Republican candidate for president and then governor of Pennsylvania. Mary Scranton had extensive connections in Washington and she exercised them assiduously on behalf of JPL, advising Murray on congressional sentiment and urging him in October 1980 to find a back-door approach to the White House, perhaps with the aid of other trustees: "Bruce, you have a good fight and an important one, and it's time to use these big guns."

With Reagan's election that November, Murray brought in the artillery. At Reagan's private victory party on election night, Caltech trustee Earle Jorgensen delivered a JPL position paper on the Halley mission to Reagan aide Michael Deaver. A week later trustee Stanley Rawn, Jr., sent the same Halley plea to Vice-President-elect George Bush in a "Dear George" letter, followed by a letter in February 1981 to Chief of Staff James Baker III ("Jimmy," to Rawn). On the day of inauguration, 20 January 1981, Murray sent a letter to Edwin Meese III pleading for the Halley mission and the future of space exploration in general.

The responses to these missives were noncommittal. As the Reagan administration settled in and the OMB budget targets began circulating in early 1981, Murray became a whirlwind, making several East Coast trips for meetings with dozens of congressional representatives and staffers, NASA and $\mathrm{OMB}$ officials, science writers and editorial boards, and key aerospace executives. He also created an institutional framework within JPL for the campaign. In January 1981 he set up the Director's Interface Group (DIG) to devise "marketing strategies," produce campaign literature, and cultivate contacts in Washington, industry, and the media. Murray also apparently hired a prominent local Republican, Robert Finch, who had access to the Reagan administration. Although Finch was not a professional lobbyist, his hiring tested and perhaps exceeded the limits imposed by the lab's relation with NASA.

JPL's campaign found endorsements from across the political spectrum. In November 1980 Senators Strom Thurmond and Alan Cranston-a Deep South Republican and a left-coast Demo- 
Right: This image of Saturn's northern hemisphere, taken by Voyager I on November 5, 1980, at a range of 9 million kilometers, shows a variety of features on a planet that, unlike Jupiter, appears very bland from Earth.

Far right: When seen from behind, Saturn's rings look very different-the bright, reflective rings we see, which are made of larger particles, turn black; other areas filled with smaller particles that diffuse sun-

light shine brightly.

Opposite page: Saturn poses for Voyager I with two of its moons, Tethys (the upper) and Dione. Bottom: Voyager I also got the first high-resolu-

tion views of Saturn's moons, including this shot of the north polar region of Rhea. These images and those from Voyager 2 revealed an amazing diversity among these hitherto unexplored bodies.
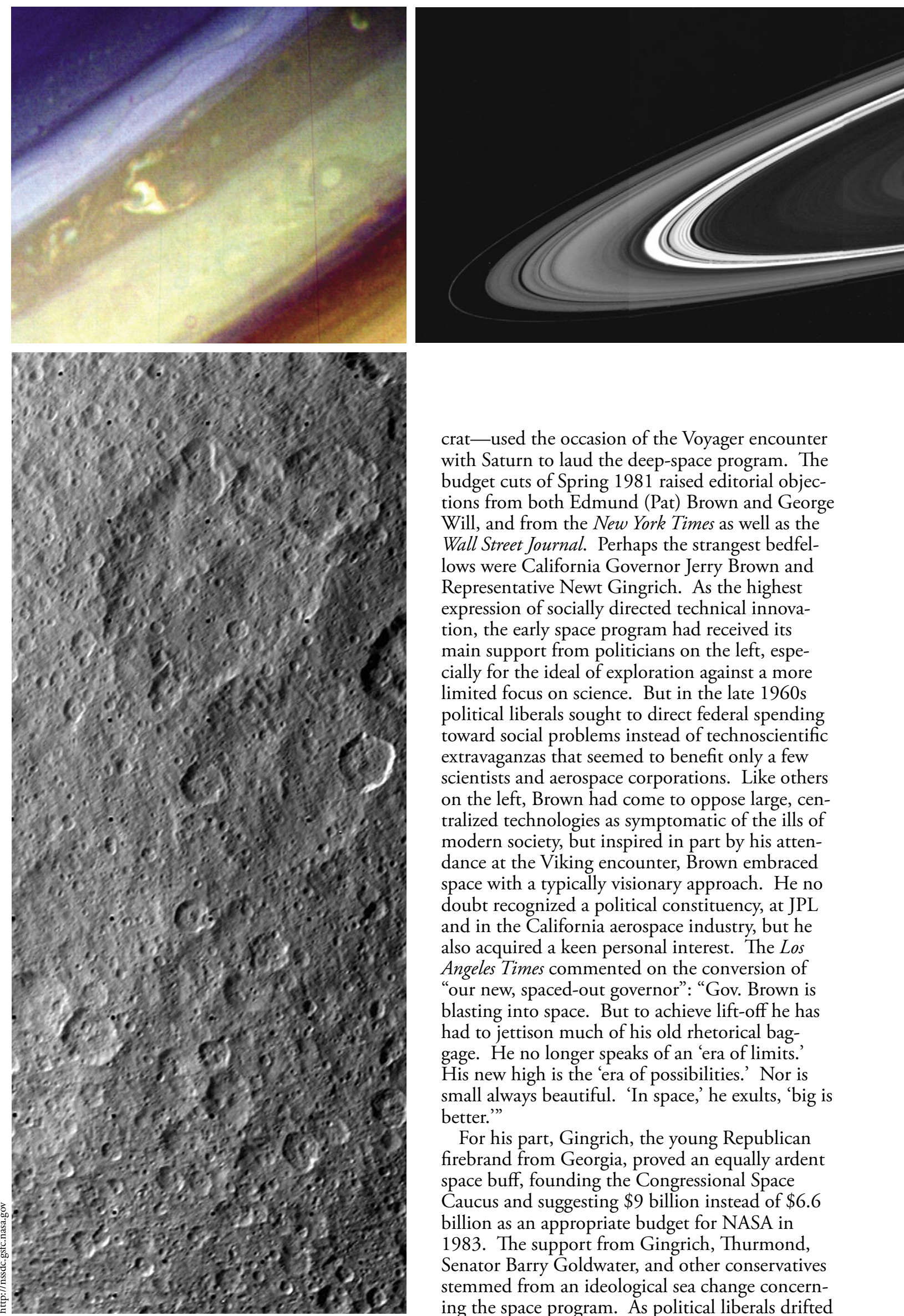

crat- used the occasion of the Voyager encounter with Saturn to laud the deep-space program. The budget cuts of Spring 1981 raised editorial objections from both Edmund (Pat) Brown and George Will, and from the New York Times as well as the Wall Street Journal. Perhaps the strangest bedfellows were California Governor Jerry Brown and Representative Newt Gingrich. As the highest expression of socially directed technical innovation, the early space program had received its main support from politicians on the left, especially for the ideal of exploration against a more limited focus on science. But in the late 1960s political liberals sought to direct federal spending toward social problems instead of technoscientific extravaganzas that seemed to benefit only a few scientists and aerospace corporations. Like others on the left, Brown had come to oppose large, centralized technologies as symptomatic of the ills of modern society, but inspired in part by his attendance at the Viking encounter, Brown embraced space with a typically visionary approach. He no doubt recognized a political constituency, at JPL and in the California aerospace industry, but he also acquired a keen personal interest. The Los Angeles Times commented on the conversion of "our new, spaced-out governor": "Gov. Brown is blasting into space. But to achieve lift-off he has had to jettison much of his old rhetorical baggage. He no longer speaks of an 'era of limits. His new high is the 'era of possibilities.' Nor is small always beautiful. 'In space,' he exults, 'big is better."

For his part, Gingrich, the young Republican firebrand from Georgia, proved an equally ardent space buff, founding the Congressional Space Caucus and suggesting $\$ 9$ billion instead of $\$ 6.6$ billion as an appropriate budget for NASA in 1983. The support from Gingrich, Thurmond, Senator Barry Goldwater, and other conservatives stemmed from an ideological sea change concerning the space program. As political liberals drifted 

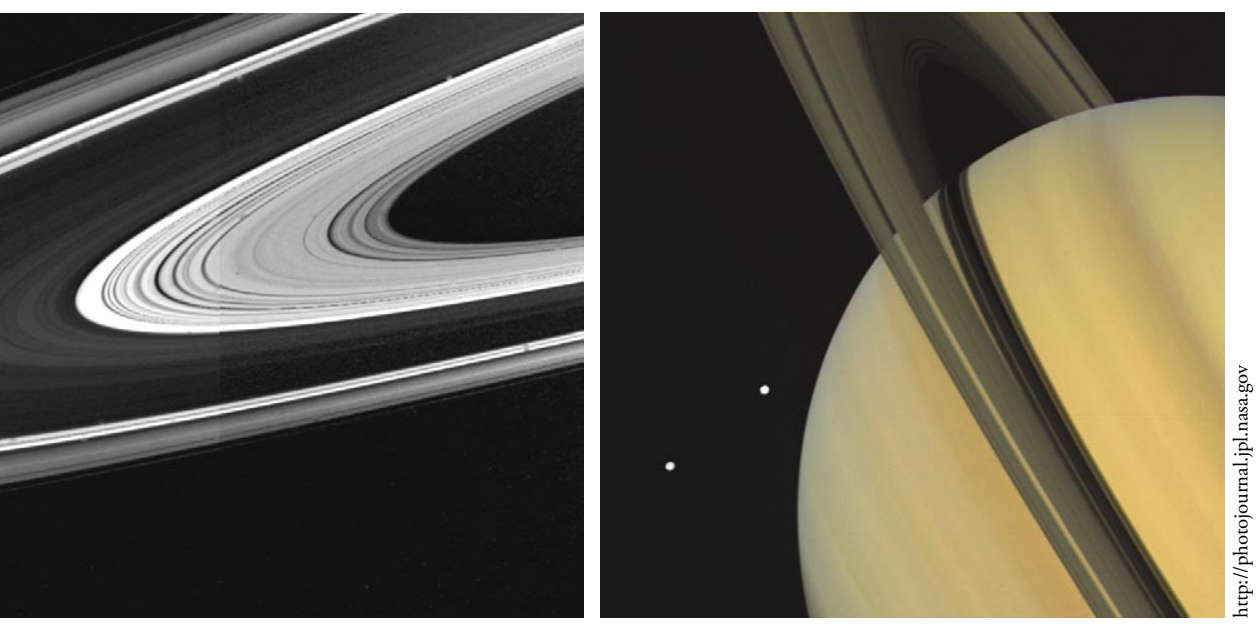

down to earth, conservatives were abandoning fiscal austerity and embracing the vision of space as new frontier first advanced by Kennedy; the space program could rekindle the old pioneer spirit, inspiring noble achievements and opening up a new realm for commerce. Liberal commentators for their part came to view the frontier myth as an emblem of imperial conquest, environmental damage, selective government subsidies, and corporate profiteering. Hence public opinion polls in the early 1980s showed that conservatives were more likely than liberals to see space spending as inadequate.

The support from political conservatives and liberal iconoclasts failed to stem the tide. Although the Reagan administration would come to extol the frontier image of space, its initial priority remained fiscal conservatism. In July 1981 Caltech president Marvin "Murph" Goldberger, prodded by Murray, created a new trustees subcommittee on JPL, chaired by Scranton, to mobilize more fully the potent influence of the trustees. The initial membership packed considerable political punch and included, among others, former Secretary

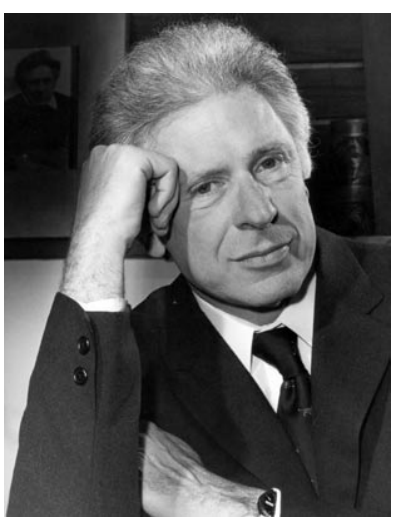

Marvin Goldberger of Defense Robert McNamara; Shirley Hufstedler, education secretary under Carter; Simon Ramo, a founder of the aerospace firm TRW and a longtime adviser to presidents; and Hollywood mogul and political insider Lew Wasserman.

As the budget crisis deepened in fall 1981 Caltech and its trustees again waded into the fray on behalf of JPL. Their preferred approach remained the back door of the White House. At the suggestion of Arnold Beckman, a longtime trustee, Goldberger in October sent a letter to Reagan via Attorney General William French Smith. Goldberger defended the deep-space program on three main grounds: intellectual curiosity, international prestige, and technological spin-offs for industry and especially defense; two of the three justifications thus derived from the cold war. Beckman followed with a letter of his own to Meese, with a more practical political justification: the cuts threatened "rapid disintegration of a 5,000-person, $\$ 400$ million Southern California enterprise. ... There are obvious implications to the support of the President and to his Party should the Administration permit such a catastrophe to take place." In addition to Scranton's persistent activity, and further interventions with Vice President Bush by Finch and Rawn, Goldberger made his own trip to Capitol Hill, where he pressed his case in particular with Senate Majority Leader Howard Baker. Baker wrote Reagan and followed up with repeated phone calls, stressing that he had no "parochial Tennessee interest" but rather a strong personal concern in the issue.

\section{DÉNOUEMENT}

The combination of Beckman's pressure on Meese and Goldberger's buttonholing of Baker proved decisive. The White House budget review committee met on 15 December 1981 to resolve the fate of the planetary program. Keyworth suggested a compromise: preserving Galileo, and hence JPL, at a cost in fiscal 1983 of $\$ 90$ million. The budget would include neither VOIR, effectively killing it, nor the Centaur upper stage, forcing yet another Galileo redesign, but the lab was safe for the immediate future.

The crisis scarred JPL, however, both externally and internally. Murray approached the political 


\section{The Space Shuttle Atlan-} tis-at long last carrying the Galileo spacecraftsoars above Florida on Oct.

18, 1989. The scene was recorded with a $70 \mathrm{~mm}$ camera by astronaut Daniel Brandenstein.
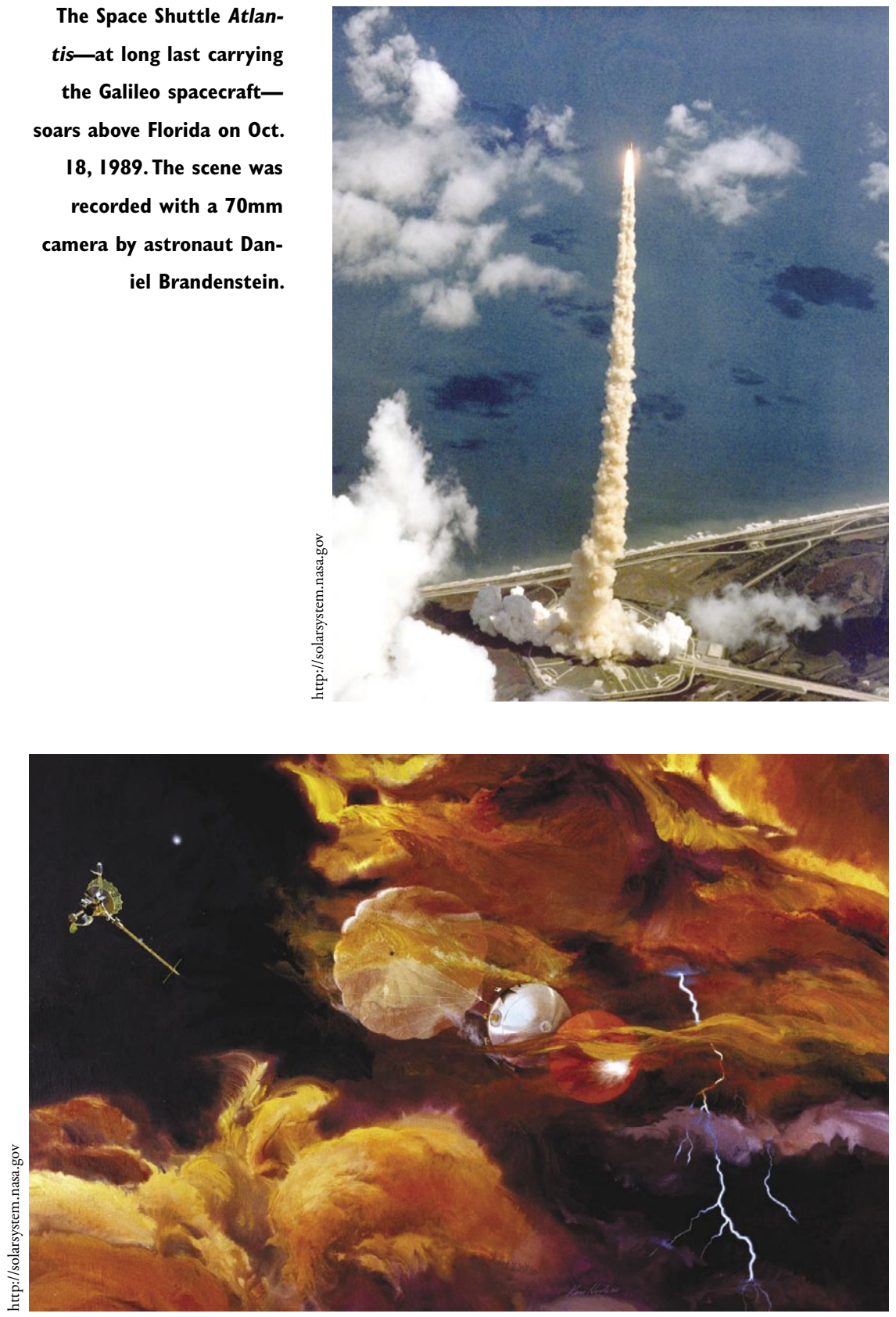

An artist's impression of Galileo's probe descending into Jupiter's atmosphere on Decem-

ber 7,1995 . The probe measured temperature, pressure, chemical composition, cloud

characteristics, sunlight, and lightning bolts during its 58-minute, 200-kilometer plunge into Jupiter's depths before being crushed, melted, and/or vaporized by the heat and pressure-the first direct analysis of a gas giant's atmosphere. battles with the enthusiasm of the true believer: "we must be zealots." Indeed, although he decried the need to play the political game, Murray seemed to relish the strategems and the chance to roll up his sleeves for a good fight. But Murray proved perhaps too zealous. His end-runs to Congress and the White House exasperated NASA. He also moved away from his pragmatic, incrementalist approach toward a harder political line. In October 1980 he chastised comet scientists for insisting on a rendezvous instead of a flyby: "The coalition got itself into the position of saying 'All or Nothing,' and it got nothing." But a few months later, as his worst fears materialized in early 1981, Murray rejected compromise, for instance, the possibility of sacrificing one mission to save another—say, forsaking Halley to preserve Galileo. "We must not permit the staff in OMB or Congress to trap us or other advocates in a no-win situation. There is no way to win by giving up one thing to get another, even if that were possible, which it normally is not. The only way to win is to protect Galileo, to get a successful reconsideration of some kind of U.S. Solar Polar mission in 1986, and to get the Halley in as an option. Anything else will mean losing. That is JPL's position." In short, Murray proclaimed to lab staff, "In the deep space area we do not bargain. ... We have to go for the whole enchilada."

Murray's tactics exposed Galileo and roused resentment at NASA and within JPL. In October I980 Murray had warned planetary scientists to provide balanced advocacy: "We have to avoid overselling of a particular mission." Some NASA managers now viewed him as doing just that on behalf of Halley and noted that "the actions taken by JPL management to 'sell' the Halley mission created, at times, the general impression that NASA and/or JPL were willing to forego the development of the Centaur and/or delay the Galileo project in the interest of committing to a Halley Intercept Mission.” They added that a 


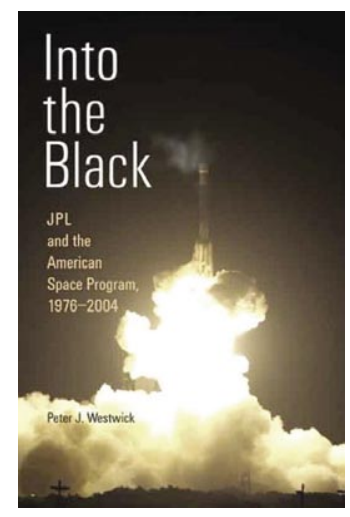

Into the Black:

JPL and the American

Space Program, 1976-2004

By Peter J. Westwick

Yale University Press

2006

408 pages

$\$ 40.00$ hardcover byproduct was morale problems on Galileo; John Casani, Galileo project manager, and others on Galileo questioned Murray's high-stakes wager with their work. Murray, for his part, viewed the Halley mission as the linchpin, "the key link in the trestle across the gorge," and he could not understand why his staff did not share his assessment. At a retreat held by the lab's executive council of senior managers, Murray asked how many thought cancellation of Halley and Venus missions would be a really serious problem. Only one person besides Murray thought it serious while fourteen others thought it not so bad.

Murray was not the only planetary scientist to mobilize politically, but his especial activism stemmed from the failure of other lobbying efforts. In fall 1981 David Morrison, chair of the Division of Planetary Sciences of the American Astronomical Society, sent a circular letter to his colleagues: "The time has come to politicize the planetary science community." But resistance to such appeals persisted among scientists, and both the division and the Space Science Board sought to preserve their objectivity by staying out of the political arena. The Planetary Society also proved an ineffectual means of influence. A society campaign organized in August 1981 to support the Halley mission generated 10,000 letters to the White House, which simply routed them all to NASA unopened.

Why did the apparent public interest in space fail to translate into political support? The planetary program had attracted unprecedented interest from the Voyager encounters and Carl Sagan's "Cosmos" and received endorsements from a range of public and political commentators. But the general American public, the ultimate underwriters of the endeavor, did not share the commitment. NBC News polls in 1980 and 1981 found that most people still thought the United States was spending too much or just enough on the space program; only one-fifth thought support was inadequate. A clear majority also thought the space program should emphasize defense over science, a view that cut across political and demographic categories. JPL itself was already starting to reflect such an orientation.
Peter J. Westwick, a visiting researcher in the Department of History at UC Santa Barbara, was previously an Olin Fellow in International Security Studies at Yale. His first book, The National Labs: Science in an American System, 1947-1974, won the Book Prize of the Forum for History of Science in America in 2004.

This book is the second volume of JPL history, picking up where Clayton Kopp's JPL and the American Space Program (Yale University Press, 1982) left off. A political and institutional history rather than a scientific one, Into the Black examines the relationship between the civil and military space programs and between manned and unmanned space programs, and the role of government as a sponsor of research for national security, international prestige, and economic competitiveness.

Westwick was given a faculty appointment at Caltech while writing the book, which was supported by grants from Ed Stone and Charles Elachi out of the JPL Director's Discretionary Fund, and had unfettered access to campus and lab archives and staff; neither institution, however, exerted any editorial control over the result.

The book's title, says Westwick, riffs on lyrics by Neil Young: "Out of the blue and into the black.... And once you're gone, you can't come back, "referring not only to a spacecraft's departure from our blue skies to the black of space, but the fact that, once launched, these highly sophisticated robots are on their ownAAA doesn't offer roadside assistance on Mars. The title also reflects the "black" of the classified military space program -JPL had largely shed its army origins by the early 1970s, only to be called into service again in the depths of the Cold War '80s. And finally, it refers to the "black" of balance sheets, in this case for a national repository of intellectual capital. 